\title{
EGÉSZSÉGTUDATOS MAGATARTÁS VIZSGÁLATA ÉS A REKLÁMOK HATÁSA AZ EGÉSZSÉGRE ÁLTALÁNOS ISKOLÁS DIÁKOK ÉS SZÜLEIK KÖRÉBEN
}

\author{
Csizmár Liliána Dóra - Szenderák János
}

\begin{abstract}
Absztrakt: Az egészséges táplálkozás kulcsfontosságú az egészségmegőrzésben. Megfelelö termék marketing hatására akkor is nő egy termék fogyasztása, ha annak vélt vagy valós egészségtelen tulajdonságai közismertek. A kutatást általános iskolás gyermekek és szüleik körében végeztük el kérdőíves felméréssel. Az eredmények kiértékelésére statisztikai összehasonlító próbákat használtunk. Az eredményeink alapján a gyermekek fontosnak itélték a táplálkozás szerepét az egészséges életmódban. Magát az egészséges étkezést föként a zöldség- és gyümölcsfogyasztással azonosították, tehát a klasszikus berögződések jelen voltak a gyermekekben. Összefüggés volt kimutatható a televízió nézés és a reklámok befolyásoló szerepe között, számos diák fogyasztott már egészségtelen terméket a reklámok hatására. Az, hogy a gyermek beleszólhatott-e a vásárlás során a megvásárolt termékek körébe, kapcsolatban állt a szülők életkorával. A szülők esetében az életkoruk és az iskolai végzettségük, valamint az iskolai végzettségük és a jövedelmük között is szignifikáns kapcsolat volt.
\end{abstract}

\begin{abstract}
Healthy diet is essential to maintaining health. However, the effective marketing of a product may increase the level of its consumption, even if its perceived or real unhealthy properties are well known. We asked various questions from children and their parents about health and healthy behaviour, which was analysed by classical statistical procedures. According to our results, the role of diet in healthy lifestyle was considered to be important for children. Healthy diet itself has been identified mainly with the consumption of vegetables and fruits, so the "classical approach" towards healthy diet was widespread. There was a connection between time spent watching television and the influence of advertising. Many students already consumed unhealthy products as a result of the former. The children's influence on the purchase of a given product showed connection with their parents' age. In the case of parents, there was a significant relationship between the age and educational attainment, we well as educational attainment and income.
\end{abstract}

Kulcsszavak: egészséges táplálkozás, oktatás, marketing, reklám

Keywords: healthy diet, education, marketing, commercial

\section{Bevezetés}

Az információk megosztása egyre nagyobb hangsúlyt kap a mindennapjainkban, kiemelten olyan területen, melyek ismertetik a táplálkozási tényezők szerepét a betegségek kialakulásában. Az egészség megőrzésével, a normális testsúly és a megfelelő, jó közérzet megtartásával különböző iparágak foglalkoznak. Emiatt egyre nagyobb szerepet kap az egészséges életmódra ösztönző vagy egészségünket javító, megőrző termékek reklámozása, melyben fontos szerepe van a médiának. A termékmarketing hatással van ránk, hiszen valóban bízva jótékony hatásában, a termék megvásárlására szánjuk el magunkat. Viszont az is igaz, hogy a médiában nagyobb részében az ún. „egészséget” (vélten vagy valósan) szolgáló termékek reklámja van túlsúlyban és kevésbé van jelen a tudományos ismeretterjesztéssel vagy egészségneveléssel foglalkozó téma. Ezen túlmenően, az írott sajtóban vagy az interneten pedig a kétséges természetgyógyászati vagy importált szenzációkat tartalmazó termékek reklámjai foglalják el a hirdetési oldalak felületeit. A Nemzeti 
Alaptantervben kötelező elem az egészségnevelés a nevelés-oktatás folyamatában. Már óvodáskortól beépítik a foglakozásokba, egészséges életmódra nevelést és gyakorlatban az étrendjükbe az egészséges élelmiszereket. Általános iskolától kezdve a középiskoláig pedig a biológia tantárgyban beépítve van jelen az egészségtan, amely néha külön tantárgyként is szerepel, ahol részletesen taglalja az egészséges életmód alkotóelemeit (Böhm, 2003). A fogyasztó társadalom igénye pedig egyre bővül. A fogyasztók többet költenek az egészségük megóvására, ami egyre nagyobb szeletet jelent az élelmiszeripari piacból. Tehát megfigyelhető az egészség felértékelődése, a kalóriamentes, a vitamindús, és a kevesebb zsír- és cukortartalmú élelmiszerek nagyobb teret nyernek napjainkban (Törőcsik, 2011). Ezért érdemes olyan irányú vizsgálatokat folytatni, ahol a termék vélt tulajdonságait, marketingjét és fogyasztását elemezzük.

\section{Szakirodalmi elemzés}

Bagdy (2010) szerint az egészségtudatosok csoportjába tartoznak azok, akik vállalják és megtesznek mindent a saját egészségük megőrzéséért, illetve gondoskodnak az egyensúlyának megteremtéséről. Az egészségmagatartás olyan összetett rendszer, melynek részét képezi a testmozgás, a higiénia, a lelki egészség és a káros dolgok kerülése. A tudatos táplálkozást továbbá kiegészíti az egészségügyi ellenőrzés és a szürővizsgálatok igénybevétele (Harris-Guten, 1979 idézi Szakály, 2008). A táplálék bevitele fenntartója az életnek, így biológiai és gazdasági szempontból fontos szerepe van. Az emberi szervezetet fontos tápanyagokkal látjuk el étkezésünk során, de nem mindegy a bevitt élelmiszer mennyisége és minősége. Hazánkban már egy ideje népbetegség közé tartozik az elhízás, melynek számos negatív következménye van. Egyre nagyobb problémákat okozhat már kisgyermek és serdülökorban is a korai elhízás, ami nehezen visszafordítható. Az ilyen fiataloknál megfigyelhető erős összefüggés a túlsúly- vagy elhízás, valamint a szülőknél létrejött magas vérnyomás-, ill. cukorbetegség között (Antal et al., 2007). A túlsúlyosság előfordulása mellett egy ellentétes trend is jellemző a mai társadalomra: erős késztetés a karcsú test elérésére és annak megtartására (Cash et al., 2004). A serdülők körében széles körben elterjedtek a testalkattal és tápláltsági állapottal lévő aggodalmak (Smolak, 2011). A fiatalok egészségmagatartását és az életmódjukat eléggé befolyásolja az otthoni példakép és szüleik hozzáállása. Azonban a fiatalok is sokat tehetnek az egészségük megőrzéséért, mivel számos lehetőség elérhető manapság (Berke et al., 2012).

Korunk felgyorsult „látó-halló” információáramlása nagymértékben kihat szokásainkra. A fogyasztók gyakran a reklámok hatására vásárolnak bizonyos élelmiszereket, vagy magas zsír- és cukortartalmú, de alacsony tápértékü termékeket. Az iskolai egészségprogramok a készségek átadásával, társadalmi támogatással segítenek a gyermekeknek abban, hogy hogyan kezdjenek törekedni a jobb, egészségesebb állapot elérésére. Ehhez szükséges a táplálkozási szokásaink megreformálása. Ennek a fejlesztésnek egyik ideális terepe az iskola, mert ott szinte minden gyermek, illetve serdülőkorú jelen van. Ez pedig nagyon jó lehetőséget kínál az egészséges táplálkozás tudás szerinti feltételeinek javítására. Számos iskolai 
programban mérték már fel az egészséges étrend hatékonyságát, e programok eredményeként mérhető változás állt be. Az egészséges életmódra való hatékony nevelés nagyban függ attól, hogy milyen a tanárok, szülők hozzáállása és kapcsolata. Fontos, hogy megfelelő tájékoztatást kapjanak a diákok az egészséges táplálkozásról (Burns et al., 2001). Napjainkban a táplálkozásunkra kihatnak az ezzel kapcsolatos reklámok, melynek eredménye az értékesítés növelése a jövedelmezőség javítása szempontjából. A reklámokat a felnőttek felfogják, értelmezik, majd szelektálják. De a gyerekeknél már nem feltétlenül így van! A gyerekek még nincsenek tisztában a reklámok alapvető céljaival, nincs realitásérzékük, döntésképtelenek abban, hogy mi számít jónak, s mi nem, vajon melyiket éri megvenni és melyiket nem. Itt jön a szülök feladata, hogy ennek megítélésében segítse gyermekét. Mert a gyermeket a legnagyobb mértékben a televízió, a barátok és a szülők befolyásolják. Ezért a szülők felelőssége, majd feladata, hogy példát mutassanak, segítsék, tanítsák meg gyermekeiket arra, hogy tudatos vásárlókká váljanak (Ranschburg, 2009).

A reklámokat látván más hatás is ér bennünket. A reklámok sokszor torzítanak, nem reális emberideálokat vetítenek elénk. A szereplöinek életvitele ellentétben állhat a valósággal. Ez hamis idillt közvetít a tökéletesnek tủnő modellek által, melynek következtében a néző frusztrálttá válik. A gyerekmüsorok vetítéséhez közel lejátszott reklámok az adott eszköz birtoklására vagy fogyasztására ösztönöznek. A gyermek könyörgésének sok szülő nem tud, és nem akar ellenállni, majd megvásárolja a terméket, ezzel elindítja a végeérhetetlen folyamatot.

A hazai táplálkozási szokások az utóbbi időkben gyakran változtak, mivel a táplálkozásunkban a hús- és tejfogyasztás, valamint zöldség- és gyümölcsfogyasztás emelkedő tendenciát mutat. Ez köszönhető a minőségi változásoknak, valamint a tudatos fogyasztói magatartásnak a helyes étrend kialakításában. A zsírtartalom csökkentése és a növényi olajok használata az egyik legfontosabb szempont, viszont a növényi olajok használata napjainkban már megosztottságot vált ki. Említésre méltó tényező a mennyiség, ami a hazai kínálási szokásokat tekintve többszöröse a valós igényeknek (Kovács et al, 2003). Hét alapkomponensböl áll az emberiség tápláléka, hat tápanyagcsoportból, melyek a fehérjék, szénhidrátok, zsírok, vitaminok, ásványi anyagok és nyomelemek, illetve a víz. További csoportosítása lehet az alapkomponenseknek a mikro és makro tápanyagok. A makro tápanyagok csoportjába tartoznak a szénhidrátok, zsírok és fehérjék. A mikro tápanyagok közé pedig vitaminok, ásványi anyagok, nyomelemek. Ide soroljuk még a bioaktív anyagokat, ezek pedig az élelmi rostok, karotinoidok, flavonoidok (Rodler, 2005). Az emberi szervezetünk többféle kémiai anyagot tartalmaz, mint például vizet, fehérjéket (aminosavak), zsírsavakat (lipidek) és nukleinsavakat (DNS és RNS). A helyes táplálkozás során figyelembe kell vennünk számos ,,alapszabályt”. A normál testsúly megtartása érdekében, például azt, hogy a fehérjék vagy a szénhidrátok legyenek-e túlsúlyban, illetve, hogy a vitaminok bevitele eléri-e az elöírt szintet. Emiatt hiányállapot alakulhat ki a szervezetünkben. Az egészségtelen táplálkozás és az egészségtelen ételek fogyasztása az immunrendszert meggyengítheti. Itt megemlíthetjük a finomított cukor fogyasztását, amely az immunsejtek mozgékonyságát, a vér egyes alakos elemeinek felületi feszültségét befolyásolja 
elönytelenül. A hozzáadott, rejtett zsiradékokat, amik a trigliceridek (neutrális zsírok) révén megváltoztatják a vér összetételét. Az „üres” ételek közvetve ronthatják a védelem hatékonyságát, valamint a lebontás során a szervezetben lévő B-vitaminok és szabályzó anyagok egy részét el is vonhatják (Tóth, 2006). Ezek magas kalóriatartalmú és alacsony rostanyag tartalmú ételek, melyek kevés egészséges tápanyaggal rendelkeznek (ezért nevezi az angolszász nyelv ,junk food" néven, vagyis „ócska ételnek”). A reklámok miatt sokan hiszik azt, hogy a gyermekek legtöbb esetben nincsenek tisztában az ételek egészségi állapotunkban betöltött szerepével, sok esetben igen manipulatív módon, érzelmi és hangulati hatásokat felhasználva mutatnak be bizonyos ételeket (Fitzgibbon-Stolley, 2006).

A jelenlegi oktatási rendszerben az általános iskolától egészen a középiskoláig nagy hangsúlyt próbálnak fektetni az egészséges életmódra és a betegségek megelözésére. Ehhez számos pályázati lehetőségek nyújtanak segítséget - pl. Menő menza -, hogy a tudatos és egyben egészséges életmód kialakítása szerves része legyen a tanulók életének. A mai világban a reklámok és a média hatása elkerülhetetlen a fogyasztó életében. Ez azt is jelenti, hogy gyakran olyan képet is mutatnak be a világról, amelynek hatására téves, nem valódi értékítélet alakul ki a fiatalokban. Arra van szükség, hogy a legkisebb miliőböl kiindulva a szülök tudatosan figyeljenek oda gyermekük nevelésére, többek között a gyermekük és a média kapcsolatára, így a negatív hatások kivédhetők. Majd tovább építkezve következik az oktatás területén az egészséges életmódra való nevelés folytatása az abban érintettek segítségével (Bene-Pusztai, 2013).

\section{Anyag és módszer}

A kutatás során egy kérdőíves felmérést végeztünk el a sátoraljaújhelyi MagyarSzlovák Két Tanítási Nyelvű Nemzetiségi Általános Iskola és Kollégium általános iskolás tanulói és szüleik körében. A kérdőívet 79 gyermek és 51 szülő töltötte ki. A két csoport (gyermekek és szülök) kitöltése egymástól függetlenül készült. Nem minden gyermek szülei vettek részt a kitöltésben, így a két minta összekapcsolása nem történt meg, így külön-külön elemeztük a szülöket és a gyermekeket. A kérdőívben 19 kérdést tettünk fel mind a két csoportnak, amelyek a táplálkozási szokásokat, a szabadidő eltöltésének szokásait, a vásárlásai szokásokat és a sportolási szokásokat járták körbe. A kitöltésben az iskola vezetősége és tanárai voltak segítségünkre, a tanárok egyben felügyelték a kitöltést és segítettek az esetleges kérdések felmerülésekor. A gyermekek esetében a háttérváltozók (kor, nem stb.) esetében kihagytuk a család anyagi helyzetére vonatkozó kérdést, mivel a gyermekek nem feltétlenül tudják helyesen megítélni a családjuk anyagi helyzetét, másrészt nem éreztük etikusnak a gyermekeket erről faggatni. A szülők esetében ezt a kérdést olyan módon tettük fel, hogy csak az átlaghoz képest kellett megmondaniuk, mennyi a jövedelmük. Ezzel a válaszadási hajlandóságot próbáltuk elösegíteni. Utóbbi tényező egyébként nem okozott problémát, mivel a tanárok kérésének megfelelően a válaszadók aktívan részt vettek a kitöltésben. A kérdéseket gyakran tovább csoportosítottuk, annak érdekében, hogy a statisztikai tesztek 
minimum feltételei teljesüljenek. Ezeket a változtatásokat az adott kérdésnél részletezzük.

Az adatok elemzéséhez khi négyzet $\left(\chi^{2}\right)$ próbát használtunk, mivel a legtöbb válasz kategorikus (nominális vagy ordinális mérési szintü) volt. A kategorikus változók esetében nem számítható átlag, így ebben az esetben a kategóriába esés számát, azaz a gyakoriságot hasonlíthatjuk össze. A $\chi^{2}$ próba megvizsgálja, hogy a két kategórián belüli eloszlás független-e egymástól (van-e köztük valamilyen kapcsolat, asszociáció) (1).

$$
\chi^{2}=\sum_{i} \sum_{j} \frac{\left(f_{i j}-e_{i j}\right)^{2}}{e_{i j}}
$$

Itt $f_{i j}$ a megfigyelt gyakoriságot jelenti az $i$-ik sorban és $j$-ik oszlopban, míg $e_{i j}$ az elméleti gyakoriságot jelenti az $i$-ik sorban és $j$-ik oszlopban. Így a tesztstatisztika $\chi^{2}$ eloszlást követ $(n-1)(m-1)$ szabadságfokkal, ahol $n$ a sorok száma, $m$ pedig az oszlopok száma (Anderson et. al, 2008). A t-próba egy egyszerü középérték összehasonlítás, a mi esetünkben két független minta között. A teszt első lépésében a két minta varianciájának azonosságát teszteljük, és ennek függvényében végezzük el a tesztet azonos vagy nem azonos varianciák mellett. A $t$-próba szerepe marginális esetünkben, mivel a változóink többsége kategorikus jellegü. A kérdőívek kérdéseit a hely hiánya miatt nem prezentáljuk, ennek ellenére az eredmények részben részletesen kifejtjük az adott kérdést és adott esetben a válaszok kategorizálását. Az elemzés során végig a standard 5\%-os szignifikancia szintet használtuk, viszont egyes helyeken a 10\%-os szignifikancia szint eredményét közöltük.

Mivel a szignifikancia szint megválasztása bizonyos keretek között önkényes, így úgy véltük, hogy a 10\%-os szignifikancia szinten érvényes eredmények közlése is hasznos lehet. Továbbá, egyes esetekben a minta elemszáma alacsony, amelyet főként a bevonható diákok és szülők köre, illetve válaszadási hajlandósága befolyásolt. Az eredményeket ennek megfelelően irányadónak tekintjük jövőbeli kutatások elkezdéséhez.

\section{Eredmények és értékelésük}

A mintában ( $\mathrm{N}=79)$, 45 fiú és 34 lány volt nemek szerinti bontásban (57\% és 43\%). A diákok közül 16,5\% második osztályos, 16,5\% harmadik osztályos, 17,7\% negyedik osztályos, $10,1 \%$ ötödik osztályos, $1,3 \%$ hatodik osztályos, $11,4 \%$ hetedik osztályos, míg $26,6 \%$ nyolcadik osztályos volt. A további elemzésekben a tanulókat alsósokra (1-5. osztály) és felsősökre (6-8. osztály) osztottuk, így részben kiszürtük azt, hogy egyes kategóriába kevesen estek. A családok nagysága átlagos volt, mivel a diákok 79,4\%-nak egy vagy két testvére volt, 17,6\%-nak három, míg mindössze $2,9 \%$-nak volt négy testvére. Ennél magasabb testvér szám nem volt a mintában. A testvéreket a további elemzéshez két csoportra osztottuk (1-2 testvér, illetve 3-4 testvér).

Megvizsgáltuk, hogy a diákok hányszor étkeztek egy nap átlagosan, amely kérdésre mindössze hárman válaszolták azt, hogy csak egyszer (3,8\%), míg a diákok $58,2 \%$-a, azaz 46 fö a kettő és négy étkezés közötti étkezést jelölte meg. Összesen 30 fő $(38,0 \%)$ étkezett átlagosan többször, mint négy. Meglepő módon viszont a 
gyermekek 30,4\% szokott csak mindig otthon reggelizni, mielőtt iskolába indul, 43\% ritkán, míg 26,6\% szinte soha. A diákok 82,3\%-a rendszeresen igénybe vette a menzát, és csak $17,7 \%$ választott más módot a déli étkezéshez. Rákérdeztünk arra is, hogy mennyire tartják egészségesnek az iskolai menzát, amelyre 30,4\% válaszolta azt, hogy egészséges, 8,9\% azt, hogy egészségtelen, míg közel $61 \%$ nem tudta megítélni (itt az „egészséges” fogalmát szabadon értelmezhették a diákok). Amikor rákérdeztünk, hogy szerintük mit jelent az egészséges étkezés, legtöbben hasonló válaszokat adtak:

- zöldség és gyümölcsfogyasztás kiemelt szerepe

- tejtermékek fogyasztása

- fehér húsok fogyasztása

- kevés zsír és cukor fogyasztása.

A diákok 12,7\%-a állítása szerint szinte soha nem iszik szénsavas, cukros üdítőitalokat. A legtöbben (54,4\%) hetente 1-3 alkalommal ittak, míg 13,9\% hetente 4-6 alkalommal. Közel 19,0\% naponta többször is fogyasztotta az említett italokat. Fontos kérdés volt az, hogy a diákok milyen gyakran fogyasztanak koffein tartalmú italokat (föleg energiaital vagy kávé). Ezeknek az italoknak a hatása különösen káros lehet fiatalkorban és túlzott bevitelben. Jótékony hatásaik ellenére sem ajánlott fiatalkorban koffeines italokat fogyasztani. A diákok állítása szerint közel 67,0\% szinte soha nem fogyasztott ilyen termékeket, de a fennmaradó 33,0\% rendszeresen fogyasztotta ezeket az italokat. A diákok 19,5\%-a 1-3 alkalommal hetente, 5,2\%-a 4-6 alkalommal hetente, 5,1\%-a naponta, míg 1 fö $(1,3 \%)$ naponta többször is. Rákérdeztünk arra is, hogy milyen gyakran isznak csapvizet/ásványvizet a folyadékbevitel esetében. Közel $9,0 \%$ szinte sosem iszik pusztán csapvizet/ásványvizet, és csak a diákok 50,6\%-a iszik naponta többször is vizet a folyadékbevitel során. Közel 40,0\% hetente néhány alkalommal választotta csak a vizet folyadékpótlásra (itt a vízfogyasztás a direkt fogyasztásra utal, ízesítés és további feldolgozás nélküli folyadékra).

Arra is rákérdeztünk, hogy mennyire tartják fontosnak a diákok a táplálkozás szerepét az egészségmegőrzésben, amelyet a diákok jelentős része fontosként jelölt meg. Egy 1-5-ig tartó Likert skálán 82,9\% az átlagnál fontosabbnak tartotta, míg $14,5 \%$ átlagosan fontosnak tartotta a táplálkozás szerepét (1. ábra). 


\section{1. ábra: A táplálkozás szerepe az egészségmegőrzésben, a diákok válaszai szerint $(\mathbf{N}=79$ fó)}

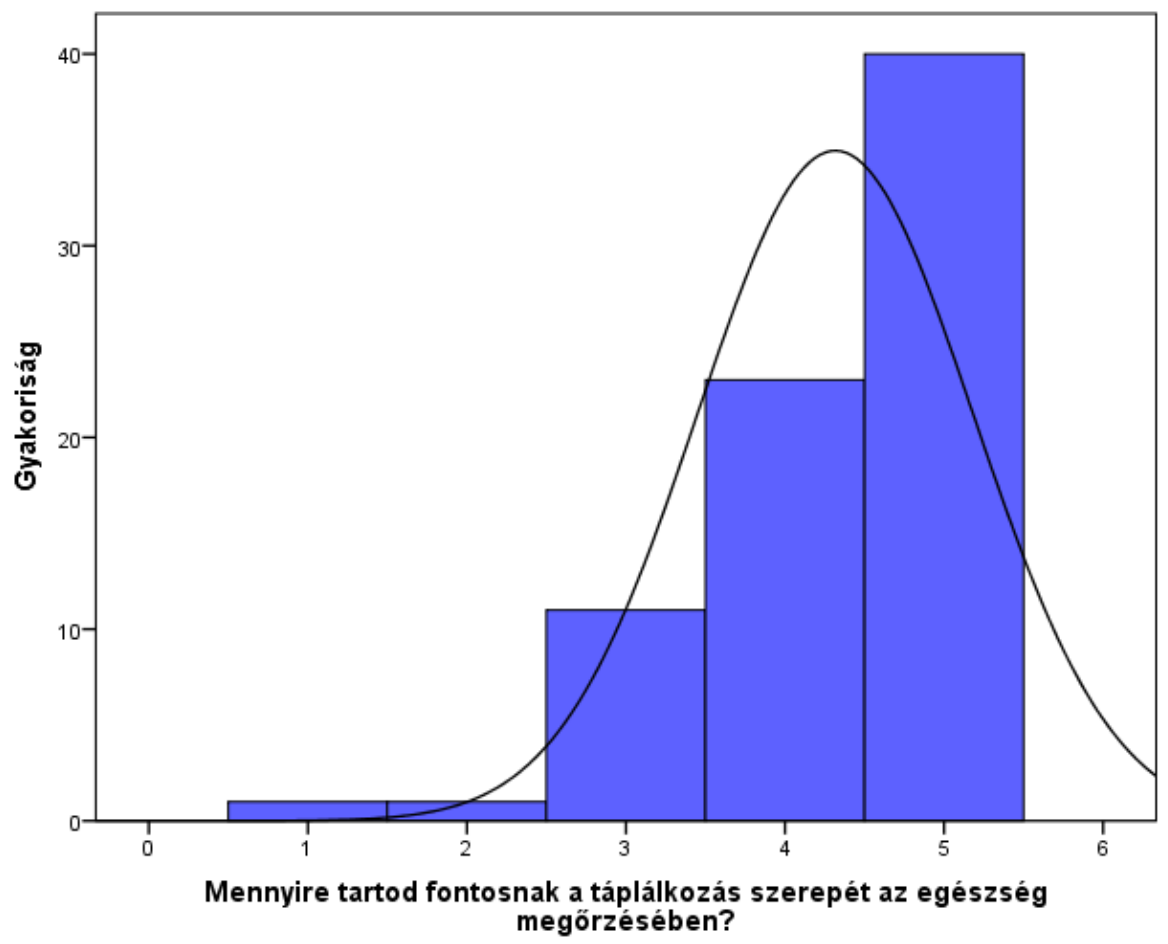

Forrás: A szerzők saját szerkesztése (2019)

A diákok közel 9,0\%-a egyáltalán nem szokott televíziót nézni, míg jelentős részük (66,7\%) csak napi 1-2 órát. Mindössze 24,4\% volt az, aki 3-4 órát, vagy annál több időt töltött televízió nézéssel egy nap átlagosan. Nagy részüknél $(50,6 \%)$ volt már, hogy olyan termékeket fogyasztottak, amikről tudták, hogy nem egészséges, de tetszett a reklámja, míg 17,7\% úgy fogyasztotta ezeket a termékeket, hogy a szüleik nem engedték. Mindössze 30,4\%-uk nem fogyasztott a tetszetős reklámok ellenére sem egészségtelen termékeket. A legtöbb tanuló (35,9\%) megvásárolna egy ismeretlen terméket csak a reklámja miatt, de csak akkor venné újra, ha tetszett volna a termék neki. Ugyanekkora hányad (35,9\%) viszont semmiképpen se venné meg. Magas azoknak is az aránya (24,1\%), akik csak a szüleik tiltása miatt nem vásároltak ilyen termékeket (2. ábra). 


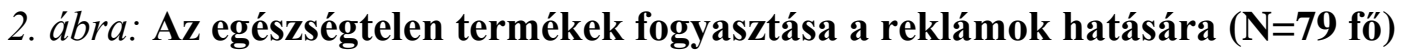

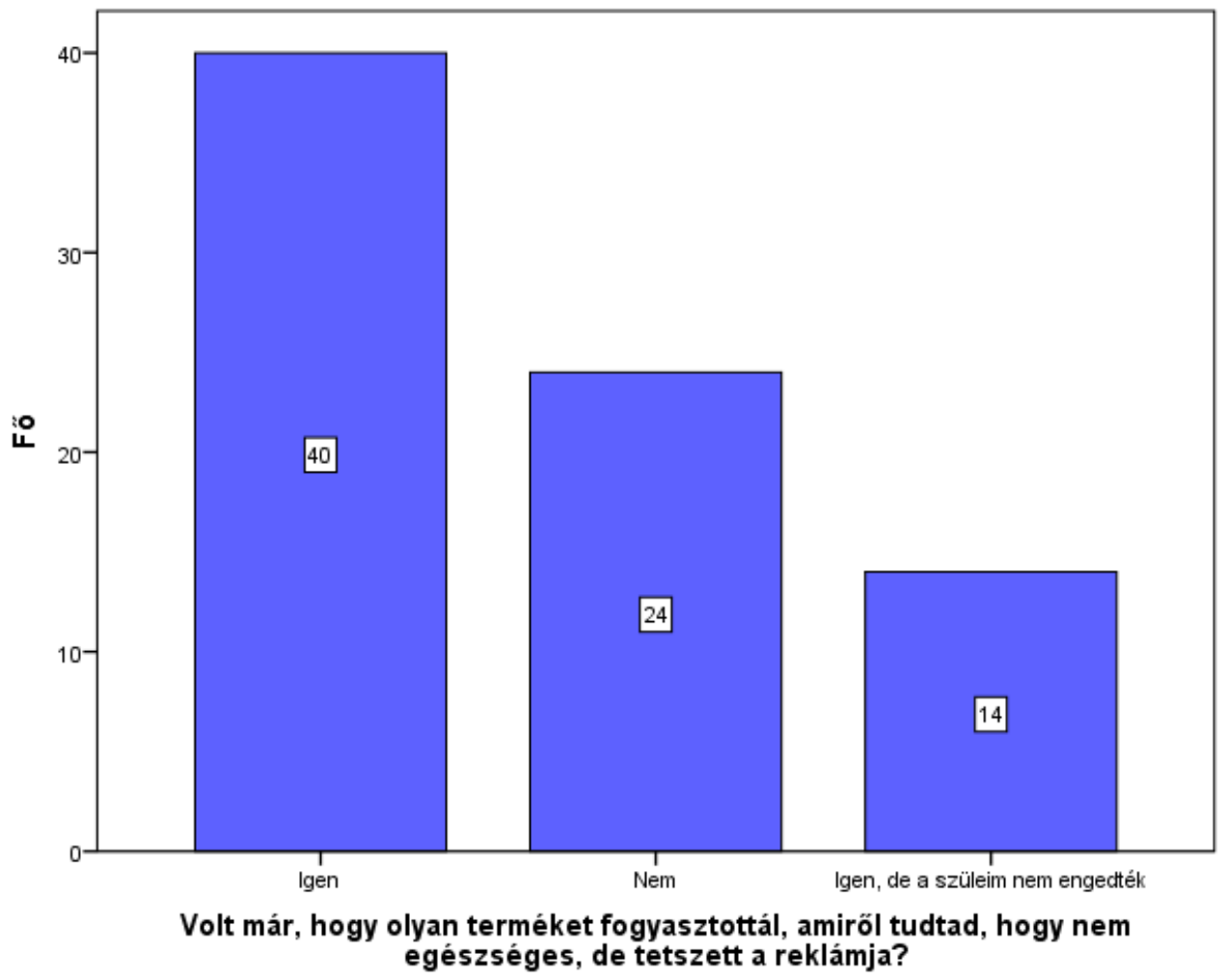

Forrás: A szerzők saját szerkesztése (2019)

\subsection{Az eredmények statisztikai vizsgálata a gyermekek esetében}

\section{Nem szerinti vizsgálat}

A diákok neme és a reggelizési gyakoriság között szignifikáns összefüggés volt $\left(\chi^{2}=5,11, p=0,08, V=0,25\right)$. A gyakorlatban ez azt jelentette, hogy a fiúk esetében jobban jelen volt a mindennapos reggelizés. A reggelizés hiánya egészségtelenebb táplálkozási szokásokra utalhat, ezért megvizsgáltuk, hogy ezek a diákok nagyobb valószínüséggel isznak-e koffeines italokat. Az eredmények viszont azt mutatják, hogy nincs kapcsolat a két változó között. A tanulók neme nem állt összefüggésben azzal a kérdéssel sem, hogy egészégesnek tartják-e a menzát. Ezen felül a koffein és vízfogyasztási szokásaik sem mutattak szignifikáns kapcsolatot. A sportolás esetében viszont szignifikáns volt a nem és a heti sportolási szám közötti kapcsolat $\left(\chi^{2}=9,58, p=0,00, V=0,35\right)$. Ez esetben föleg a fiú tanulók esetében volt magasabb a heti sportolási alkalmak száma. A vásárlási szokások és az adott diák neme több esetben is összefüggést mutatott. A tévénézési szokások szignifikánsan különböztek a nemek szerint $\left(\chi^{2}=7,90, p=0,01, V=0,32\right)$. Ezen felül viszont a diákok neme nem mutatott szignifikáns kapcsolatot azzal a kérdéssel kapcsolatban, amely szerint volt már, hogy olyan terméket vásároltak, amelyről tudták, hogy nem egészséges, de tetszett a reklámja. Azt, hogy az adott diák megvásárolna-e egy ismeretlen terméket csak a reklámja miatt „Inkább megvenné” 
és „Inkább nem venné meg” kategóriákba csoportosítottuk. Ez szignifikáns kapcsolatban állt a diákok nemével $\left(\chi^{2}=4,43\right.$ p-érték: $\left.0,03, V=0,24\right)$. A lány diákok többen válaszolták azt, hogy csak a reklámok hatása miatt nem vásárolnának meg egy ismeretlen terméket. A diákok neme viszont nem állt kapcsolatban azzal, hogy fogyasztanak-e egészségtelen terméket pusztán azért, mert a reklámja tetszik.

\section{Életkor (osztály) szerinti vizsgálat}

Életkor (osztály) szerint alsósokra és felsősökre osztottuk a diákokat. Az adott tanuló osztálya és a reggelizés között nem volt szignifikáns kapcsolat. Az elemzés következő részéhez a koffeinfogyasztási szokásokat két részre osztottuk. Azokra, akik szinte soha nem fogyasztottak koffeines italokat, illetve azokra, akik hetente legalább 1-3 alkalommal fogyasztottak. Az eredmények szerint nem volt összefüggés a diákok neme és a koffeinfogyasztási szokások között. Meglepő módon az alsósok és a felsősök véleménye szignifikánsan eltért arról, hogy egészséges-e a menza $\left(\chi^{2}=4,90, p=0,03, V=0,25\right)$. Ez esetben az alsósok többször ítélték egészségesnek (saját megítélésük szerint), viszont mindkét kategóriában többen voltak azok, akik nem tudták megítélni azt. Az, hogy a diák alsó vagy felső éves volt, nem állt összefüggésben azzal, hogy fogyasztott-e olyan terméket, amiről tudta, hogy nem egészséges, de tetszett a reklámja.

\section{A tévénézés és a vásárlás összefüggése}

Miután a nem és az életkor szerinti összefüggéseket megvizsgáltuk, rátértünk a központi kérdésre, miszerint összefüggés volt-e a reklámok hatása és a vásárlási szokások között. A táplálkozás szerepét vizsgáló kérdést két részre osztottuk: 1-3-ig az átlagos, vagy az alatti fontosságot tulajdonító egyénekre, és a 4-5-ig az átlag fölötti fontosságot tulajdonító egyénekre. Az első kategória két fő kivételével az átlagos értéket (3) adta, így az átlag alatti fontosságot tulajdonítók szerepe elhanyagolható volt. Nem meglepő módon viszont szignifikáns kapcsolat mutatkozott a televízió nézés mennyisége és a reklámok hatása között $p=0,03$ értékkel. Mivel itt szintén nem teljesült egy minimumfeltétel ( 5 helyett 3,45 volt a várható érték egy cellában), az „Inkább igen” és az „Inkább nem” válaszok szerint csoportosított változót használtuk tovább. Ebben az esetben a kapcsolat viszont eltünt $\left(\chi^{2}=2,26, p=0,13\right.$, $V=0,17)$. Ennek ellenére a $p$-érték közel maradt a $10 \%$-os küszöbértékhez. Azok a diákok, akik fogyasztottak már egészségtelen terméket a reklám hatására, valószínübben vásároltak volna meg egy terméket, aminek számukra kedvező a reklámja $\left(\chi^{2}=9,32, \quad p=0,00, \quad V=0,34\right)$ vagy egy híres színész reklámozza $\left(\chi^{2}=11,62, p=0,00, V=0,38\right)$.

Azt, hogy az adott diák megvásárolna-e egy ismeretlen terméket csak a reklámja miatt a televíziónézés idejétől sem független $10 \%$-os szignifikancia szinten $\left(\chi^{2}=3,26, p=0,07, V=0,20\right)$. A diákok csak kevés hányada $(26,9 \%)$ vett volna meg azért egy terméket, mert egy híres színész reklámozza, 48,7\%-uk viszont semmiképpen se vette volna meg csak ezért. Közel $16,7 \%$ viszont azért nem vette volna meg, mert a szülei valószínüleg nem engedték volna. Ezt a kérdést szintén „Inkább megvenné” és „Inkább nem venné meg” kategóriákba csoportosítottuk. Erös összefüggést mutatott az, hogy akik megvásárolnának egy ismeretlen terméket, csak mert tetszik a reklámja miatt, azok megvásárolnák akkor is, ha egy híresség 
reklámozná az $\left(\chi^{2}=20,32, p=0,00, V=0,51\right)$. Továbbá kapcsolat volt aközött is, hogy akik fogyasztottak már olyan terméket, amiről tudták, hogy nem egészséges, de a reklámja vonzó volt, azok megvásárolnának egy terméket is csak a reklámja miatt $\left(\chi^{2}=7,70, p=0,00, V=0,31\right)$.

\subsection{A szülők eredményei}

A szülők nagy része házas volt (74,5\%), míg kisebb részük egyedülálló $(13,7 \%)$. Néhány százalék volt mindössze az elváltak és az özvegyek aránya. Az iskolai végzettségben az egyetem dominált 43,1\%-kal, ezt követte 29,4\%-kal az érettségi, 17,6\%-kal a szakmunkásképző, míg 10,0\% alatt volt a 8 általános (vagy az alatt) végzők aránya. A kitöltők nagy része 45 év alatti volt (60,8\%), míg 39,2\% volt a 45 év felettiek aránya. A családi jövedelmet a szülők 62\%-a átlagosnak írta le, 7,8\% az átlagnál kicsit magasabbnak, míg a fennmaradó rész az átlagnál valamivel/jóval alacsonyabbnak (3. ábra). Jellemző volt az átlagos családméret aránya a mintában, ahol 43,1\% esetében 4 fö, 25,5\% esetében 5 fö volt a családnagyság. Közel 19,6\% esetében 2 fö volt a családméret, ők jellemzően az egyedülálló vagy elvált szülők voltak.

\section{3. ábra: A családi jövedelmek megítélése a szülők által ( $\mathbf{N = 4 2}$ fö)}

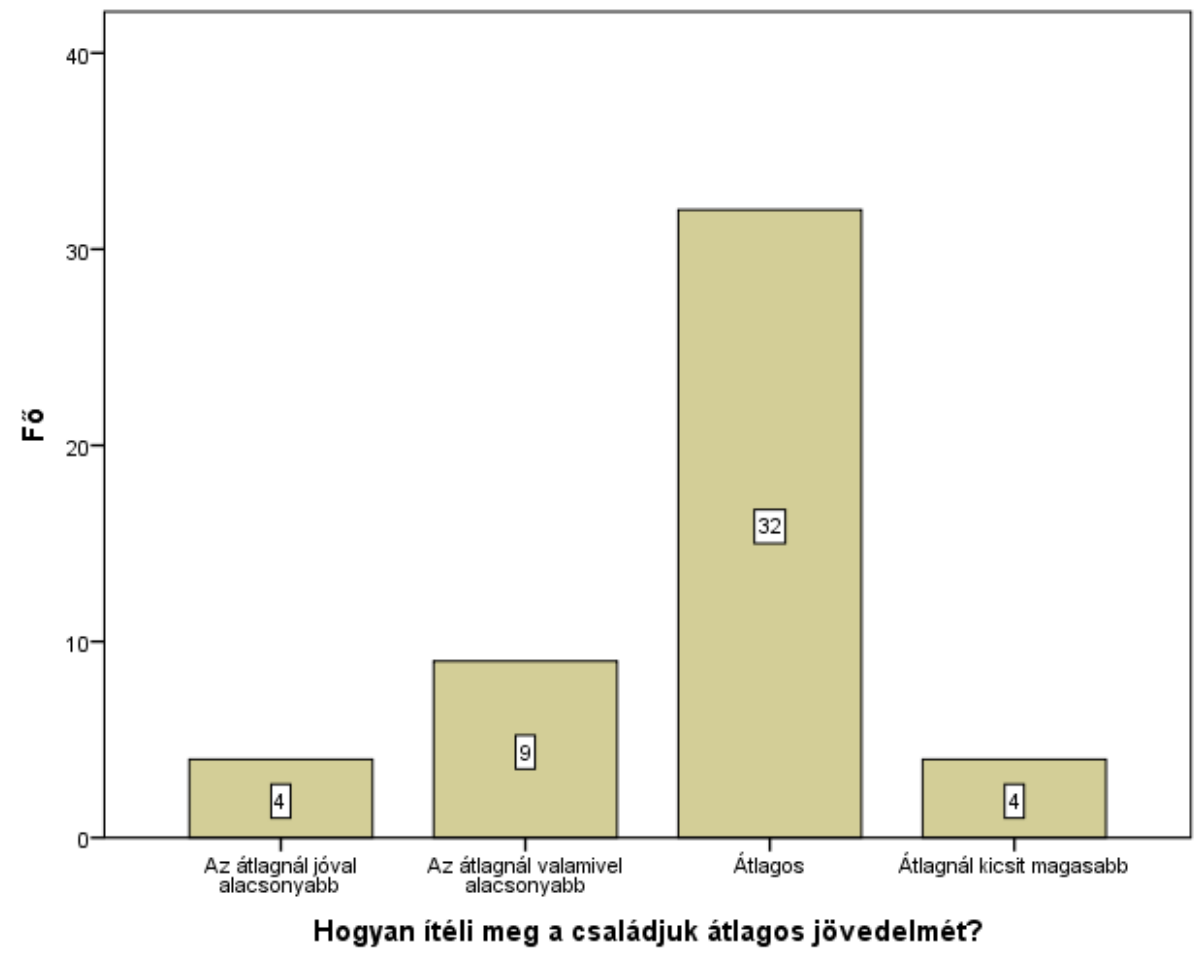

Forrás: A szerzők saját szerkesztése (2019)

A szülők 76,5\%-a állította azt, hogy a bevásárlásnál előfordult már, hogy a gyermeke ajánlására vásároltak meg valamilyen terméket. Közel 68,6\%-uk szerint a gyermek az adott terméket a televízióban láthatta. A többség esetében $(88,2 \%)$ 
elöfordult, hogy olyan élelmiszert kért a gyermek, amit a televízióban reklámoztak. Meglepő módon a szülők állítása szerint nem az ár, hanem a minőség befolyásolta elsősorban azt, hogy a szülők milyen élelmiszert vásároltak (56,9\%), míg 29,4\% számára az ár volt a meghatározó. A fennmaradó 13,7\% számára egyéb tényezők voltak hatással. A szülök nagy részét (több mint $72 \%$ ) ritkán befolyásolja a látott vagy hallott élelmiszerek reklámja, 21,6\%-ot pedig soha, állításuk szerint. Amikor reklám utáni élelmiszert vásárolnak, akkor föleg az új kipróbálásának élménye a döntő (58,8\%), illetve az, ha a terméket az egész család kedveli (15,7\%) (4. ábra).

\section{4. ábra: A reklámok utáni élelmiszervásárlás főbb tényezői ( $\mathbf{N = 5 1 ~ f o ̈ ) ~}$}

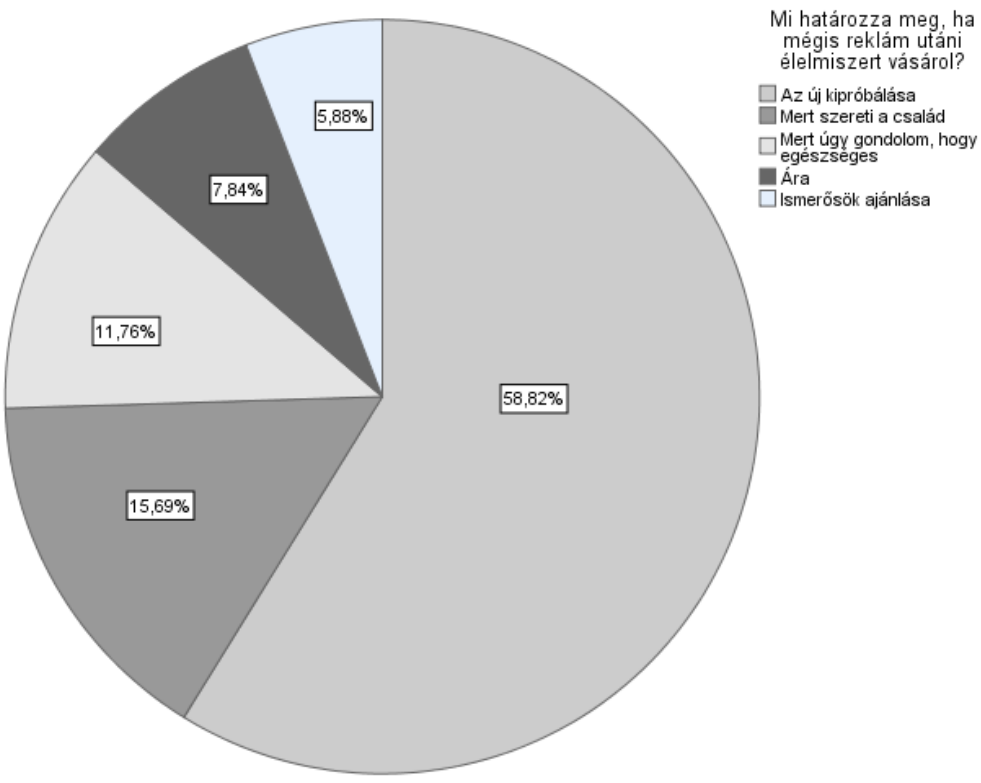

Forrás: A szerzők saját szerkesztése (2019)

A szülők közel 12\%-a akkor vásárolt, ha úgy gondolta egészséges, míg 6-8\% körül volt azoknak az aránya, akiket az ár vagy az ismerösök ajánlása befolyásolt. Az iskolai étkezéssel kapcsolatban megkérdeztük, hogy a szülök mennyire tartják egészségesnek a menzát. A szülök fele (51\%) részben egészségesnek tartotta a menzát, és közel egyenlő arányban volt azok aránya, akik szerint egészséges, és akik nem tudták megítélni (25,5 és 23,5\%). Maga az egészséges étkezés föleg a beltartalmi értékek meglétét, a jó minőséget és alapanyagot jelentette számukra. A válaszaikban gyakoriak voltak az alábbi tényezők:

- zöldség és gyümölcsfogyasztás, mint domináns tényezö

- változatos étrend

- többen kiemelték a jó minőségü alapanyagot

A gyermekek fogyasztását (abban az esetben, ha nem a szülő biztosítja az élelmiszert, tehát például a gyermek magának vásárol), a szülők szerint főleg az otthon látottak befolyásolhatja (65\%). Közel 30\% körül volt azoknak az aránya, akik szerint vagy a televízió/internet, vagy a barátok ajánlásai volt az elsődleges ok. A 
szülők nagy része, közel 47\%-a egy héten többször is sportolt, 39,2\% pedig nem, de a tervei között szerepelt. Mindössze 13,7\% volt azok aránya, akik sosem sportoltak. Életkor szerinti csoportosítás eredményei

Az életkort 45 év alattiak és 45 év felettiek szerint csoportosítottuk, annak érdekében, hogy a khi négyzet próba feltételei teljesüljenek. Az elemzés szerint kapcsolat volt a szülők életkora között, illetve aközött, hogy a bevásárlásnál a gyermek beleszólt-e a vásárlásba $\left(\chi^{2}=3,34, \quad p=0,06, \quad V=0,25\right) \quad 10 \%$-os szignifikancia szinten. Az életkor már nem mutatott kapcsolatot azzal, hogy a szülők szerint ezeket a termékeket a gyerek vajon a tévében láthatta-e. Nem volt kapcsolat a szülök életkora között és a sportolási szokásaik között, illetve az életkor és a családméret között sem. Viszont erős szignifikáns kapcsolat volt a szülők életkora és iskolai végzettsége között $\left(\chi^{2}=13,61 p=0,00, V=0,52\right)$. Ez esetben látható, hogy a 45 év alatti szülők föleg középszintü végzettséggel rendelkezett (31 szülőből 24 közép, míg 7 felső végzettséggel rendelkezett, míg 20 fö 45 feletti szülőből 15 felső, míg 5 középvégzettséggel).

\section{Jövedelem szerinti csoportosítás eredményei}

A szülők jövedelmét tovább csoportosítottuk az elemzésekhez. A jövedelmet két kategóriába lehetett osztani, átlagnál valamivel/jóval alacsonyabb, vagy átlagos/átlagnál valamivel magasabb. Mivel az átlagnál valamivel magasabb jövedelmet mindössze 4 fö jelölte meg, míg az átlagnál jóval magasabbat senki, ezért előbbi kategóriát az átlagoshoz soroltuk. Az életkor és a jövedelem között nem volt szignifikáns kapcsolat, sem a jövedelem és a családméret között. Lehetséges, hogy a magasabb jövedelmű szülők könnyebben megengedik az új termék megvásárlását. A szülők jövedelme viszont nem mutatott összefüggést azzal, hogy a bevásárlásnál a gyermek beleszólhatott abba, mit vásároljanak meg. Ezen felül családi jövedelem nem mutatott kapcsolatot azzal, hogy a szülők sportoltak-e, de erős összefüggés volt viszont a szülők jövedelmi helyzete és az iskolai végzettség között $\left(\chi^{2}=3,40\right.$, $p=0,06, V=0,26) 10 \%$-os szignifikancia szinten. Nem volt összefüggés viszont a család mérete és a szülők iskolai végzettsége között. Ezek a tényezők a szülők tényezőinek megértését segíthetik elő.

\section{Következtetések, összegzés, záró megjegyzések, záró gondolatok}

Az egészséges táplálkozás kulcsfontosságú az egészségmegőrzésben, viszont az adott termék marketingje befolyásolhatja a termék megítélését. Így könnyen előfordulhat, hogy a megfelelő marketing hatására akkor is nő egy termék fogyasztása, ha az a köztudatban egészségtelenként van elkönyvelve. Különösen a fiatalkorú gyermekek esetében kérdéses mennyire ismerik az egészséges táplálkozás fogalmát, mennyire követik azt, illetve mekkora szerepe van a szülőnek abban, hogy ezt a gyermek elsajátítsa. A gyermekek és a szülök esetében is kevés összefüggés volt kimutatható a reklámok hatását illetően, viszont néhány jelenség egyértelmüen beazonosítható volt. A gyermekek számára fontos volt a táplálkozás szerepe az egészséges életmódban, többség átlag fölötti fontosságot tulajdonított neki. Magát az egészséges étkezést föként a zöldség- és gyümölcsfogyasztással azonosították, tehát a klasszikus berögződések jelen voltak a gyermekekben. A gyermekek 
viszonylag magas hányada rendszeresen fogyasztott koffein tartalmú termékeket, amely nem mutatott összefüggést a személyes karakterisztikáikkal. Összefüggés volt kimutatható a televízió nézés és a reklámok befolyásoló szerepe között, számos gyermek fogyasztott már egészségtelen terméket a reklámok hatására. Továbbá akik vásároltak már egészségtelen terméket a reklámok miatt, ott kimutatható kapcsolat volt azzal, hogy akkor is vásárolnának ilyen terméket, ha tetszene a reklámja vagy egy híresség reklámozná. A szülök esetében sokkal kevesebb összefüggés volt kimutatható. Az, hogy a gyermek beleszólhatott-e a vásárlás során a megvásárolt termékek körébe, kapcsolatban állt a szülök életkorával, de nem mutatott kapcsolatot egyéb tényezőkkel. A szülők esetében az életkoruk és az iskolai végzettségük, valamint az iskolai végzettségük és a jövedelmük között is szignifikáns kapcsolat volt. Az eredmények nem általánosíthatók nagyobb csoportokra, mivel a kérdőíves felmérés egy szük körben történt, ennek ellenére a felismert kapcsolatok elözetesen is várhatóak voltak. A fent prezentált eredmények képezhetik egy nagyobb hangsúlyú elemzés bevezetését, amely pontosabb betekintést nyújthat a reklámok által kifejtett hatásokba.

\section{Köszönetnyilvánítás}

Magyar nyelven: „A publikáció elkészítését az EFOP-3.6.1-16-2016-00022 számú, Debrecen Venture Catapult Program címü projekt támogatta. A projekt az Európai Unió támogatásával, az Európai Szociális Alap társfinanszírozásával valósult meg." Angol nyelven: „The work/publication is supported by the Debrecen Venture Catapult Program, EFOP-3.6.1-16-2016-00022 project. The project is co-financed by the European Union and the European Social Fund."

\section{Irodalomjegyzék}

Anderson, D. R., Sweeney, D. J., Williams, T. A. (2008): Statistics for Business and Economics. Thomson South-Western. ISBN 13: 978-0-324-36507-8 pp 1-1054.

Antal, M., Biró, L., Regöly-Mérei, A., Nagy, K., Arató, G., Szabó, C., Martos, É., Péter, S. (2007). Methods for the assessment of adolescent obesity in epidemiological studies. Orvosi hetilap, 149 (2): 51-57.

Bagdy E. (2010): Hogyan lehetnénk boldogabbak? Kulcslyuk Kiadó, Budapest.

Berke Sz., Huszka P., Laki-Lukács A., Iglói N. (2012): Az egészséges életmód és a testmozgás megítélése kaposvári fiatalok körében In: Fejér-Király G., Lázár E. (szerk.) Vállalkozói és gazdasági trendek a Kárpát-medencében I. kötet. Státus Kiadó, Csíkszereda. 86-97.

Bene Z., Pusztai V. (2013): Médiaelmélet. Online jegyzet. <http://www.jgypk.hu/ mentorhalo/tananyag/MediaelmeletV2/viii25_a_reklmok_befolysol_ereje.html> (2018.09.25.)

Böhm, G. (2003): Emotional reactions to enviromental risks. Journal of Environmental Psychology, 23. 199-212.

Burns, C., Jansen, J., Schuit, J., Seidell, J. (2001): Mit eszik a család? - Egészségfejlesztés a táplálkozás tükrében. In Boddy, D. (szerk.): Bizonyitékok az egészségfejlesztés hatékonyságára I. Bizonyitékok könyve. Országos Egészségügyi Információs Intézet és Könyvtár, MEDINFO, Budapest.

Cash, T. F., Morrow, J. A., Hrabosky, J. I., Perry, A. A. (2004): How has body image changed? A cross-sectional investigation of college women and men from 1983 to 2001. Journal of Consulting and Clinical Psychology, 72 (6): 1081-1089. 
Fitzgibbon, M. L., Stolley, M. (2006): Promoting health in unhealthful environment: Lifestyle challenges for children and adolescents. Journal of the American Dietetic Association, 106: 518 522

Kovács J., Szabó É., Szilágyi M. (2003): Komplex szürövizsgálatok középiskolások körében Hódmezővásárhelyen. In: Kaposvári J. (szerk.): Nemzeti iskolaegészségügyi konszenzus konferencia (Háttéranyagok). Budapest.

Ranschburg J. (2009): Áldás vagy átok? Gyerekek a képernyő elött. Saxum Kiadó, Budapest.

Rodler I. (2005): Élelmezés- és táplálkozás-egészségtan. Medicina Könyvkiadó, Budapest.

Smolak, L. (2011). Body image development in childhood. In T. F. Cash, \& L. Smolak (Eds.), Body Image: A handbook of science, practice, and prevention (2nd ed.) (pp. 67-75). New York: The Guilford Press.

Szakály Z. (2008): Hagyományos magyar termékek piaci lehetőségeinek elemzése. Élelmiszer, Táplálkozás és Marketing, 5 (2-3): 57-65.

Tóth G. (2006): Betegtáplálékaink. A szalmonellától a madárinfluenzáig - és azon túl. Pilis-VetKiadó Bt., Pilisvörösvár.

Törőcsik M. (2011): Fogyasztói magatartás. Insight, trendek, vásárlók. Akadémiai Kiadó, Budapest. 